\title{
Structural risk analysis of a potential Ebola outbreak with respect to infrastructural aspects amid the current COVID-19 pandemic
}

\author{
MOHAMED ARAFKAS $^{1 *}$, ISSIDEEN AYINLA OSSENI ${ }^{2 *}$, JUSTYNA SCHUBERT $^{3}$, \\ JACEK BANIA $^{3}$, JOANNA KULAS ${ }^{3}$, VERIA KHOSRAWIPOUR ${ }^{1}$, MAYA KARINE LABBÉ ${ }^{4}$, \\ PIOTR FRELKIEWICZ ${ }^{5}$ and TANJA KHOSRAWIPOUR ${ }^{6}$
}

\author{
${ }^{1}$ Department of Plastic Surgery, Petrus Hospital, D-42283 Wuppertal, Germany; ${ }^{2}$ Department of Medicine, \\ UAC Health Sciences Faculty, 01 BP 526 Cotonou, Benin; ${ }^{3}$ Department of Food Hygiene and Consumer Health Protection, \\ Wroclaw University of Environmental and Life Sciences, 50-425 Wroclaw; ${ }^{4}$ School of Dentistry, Wroclaw Medical University, \\ 50-367 Wroclaw; ${ }^{5}$ Center of Experimental Diagnostics and Innovative Biomedical Technology, Wroclaw University of \\ Environmental and Life Sciences, 50-375 Wroclaw, Poland; ${ }^{6}$ Department of Surgery (A), \\ University Hospital Duesseldorf, Heinrich-Heine University Duesseldorf, D-40225 Duesseldorf, Germany
}

Received March 6, 2021; Accepted June 22, 2021

DOI: $10.3892 / \mathrm{mi} .2021 .7$

\begin{abstract}
Due to the ease and increased volume of global interaction, it remains unclear whether the current coronavirus disease (COVID-19) pandemic will be a one-off event or whether the world is at risk of recurrent pandemics as a result of globalization. To address this important issue, the present study assessed the risk of a possible future Ebola pandemic. The risk profile of Hubei province in China was compared with that of the Democratic Republic of Congo (DRC) in terms of travel and infrastructure, since DRC is considered a major epicenter for Ebola outbreaks. Recurrence patterns of previous Ebola outbreaks were analyzed in a cumulative outbreak model. Internationally available data on air traffic, flight destinations, passenger numbers, population density, distribution and domestic traffic routes were all analyzed and compared between the DRC and Hubei province. DRC is a major epicenter for Ebola outbreaks, with 13 recorded outbreaks from 1976 until 2020. International airports at both Kinshasa, the capital city of the DRC and Wuhan, the capital city of Hubei province, are heavily frequented destinations and represent major transfer hubs on their respective continents. Volumes of flights to and from extracontinental destinations account for $<25 \%$ of total flights at both airports with similar
\end{abstract}

Correspondence to: Dr Tanja Khosrawipour, Department of Surgery (A), University Hospital Duesseldorf, Heinrich-Heine University Duesseldorf, Moorenstrasse 5, D-40225 Duesseldorf, Germany

E-mail: tkhosrawipour@gmail.com

*Contributed equally

Key words: pandemic, coronavirus, COVID-19, Ebola, Democratic Republic of Congo, China total international passenger volumes. However, the volume of domestic commuting by aviation is $>30$-fold higher at Hubei province compared with that of the DRC. This finding is also reflected by the higher population density and homogeneity in terms of population per square kilometer in Hubei. Following the analysis of decades of Ebola reports, it became evident that the DRC remains a hotspot for potential Ebola outbreaks in the future due to constantly recurrent local outbreaks. In terms of the international aviation network, numerous important similarities between Kinshasa and Hubei Province were observed as regards connectivity. The present comparative analysis extends beyond biological factors underlying Ebola and COVID-19 transmissions and confirms that the DRC, Kinshasa in particular, is not a remote location. Although internal commuting and population density may be lower in the DRC compared with those in Hubei province, integration into the international aviation network is similarly extensive. The international community must increase its focus and efforts in preventing another possible global pandemic commencing in Africa, and in particular the DRC.

\section{Introduction}

The coronavirus disease (COVID-19) outbreak, which began in Wuhan of Hubei province in China as its initial epicenter in late 2019, has adversely affected the lives of millions worldwide. As a result of the rising numbers of confirmed cases, the COVID-19 pandemic has become a new reality. Considering the extent of globalization and prevalence of global commuting, several experts have argued that this pandemic was a predictable event and not a random occurrence. Indeed, over the past decades, multiple viral outbreaks have been observed in China alone, including the Hong-Kong Influenza virus between 1968 and 1969, the severe acute respiratory syndrome between 2002 and 2004 and the current COVID-19 pandemic. The fast dynamic of this pandemic, which is most likely facilitated by the high volume of international air traffic (1), renders it 
also noteworthy to investigate Ebola, which is a more lethal viral disease compared with COVID-19 that is also subject to regular outbreaks. In addition, current knowledge on the biology and transmission of the virus that causes Ebola is limited (1-3). Prior to this current COVID-19 outbreak, a large Ebola epidemic occurred in West Africa, which spanned over several countries, including Guinea, Sierra Leone and Liberia from 2014 until 2016. The scale of this Ebola epidemic, combined with a few local factors, resulted in the appearance of international Ebola cases outside of Africa, which had not been previously observed (4). This new epidemiological profile of Ebola has caused widespread concerns among policy makers and healthcare professionals (5). Observations during the initial COVID-19 outbreak and its development into a global pandemic have provided valuable information in terms of virus spread patterns, efficacy of containment efforts $(6,7)$, the effectiveness of viral detection strategies (8), the implementation of travel restrictions $(1,9)$ and distribution patterns in different communities. Therefore, as countries on the African continent transform into important global players with increased international participation, it becomes crucial to analyze the potential risks of a potential Ebola pandemic.

Therefore, the aim of the present study was to conduct a risk assessment by considering important factors that may facilitate the spread of Ebola with possible subsequent pandemic dimensions. These factors include population and infrastructural density and international flight traffic volume.

\section{Data and methods}

Data availability. Analysis of the current data regarding different parameters, including transportation, international flight routes and passenger volume, was difficult for the DRC and Hubei province. Data quality and availability on air traffic and commuting varied markedly in these two regions. The present analysis includes the most recent and comprehensive data.

Data sources. Both International passenger numbers and international flight routes with 'Kinshasa International Airport' and 'Wuhan International Airport' as destinations were retrieved from data provided by the respective airports on their official websites and the Center for Aviation (www. centreforaviation.com). The most recent data available for the DRC are from 2014 (www.kinshasa-airport.com), whilst Wuhan International Airport can provide more recent data from 2019 up to the present day (www.wuhan-airport.com). Population and distribution data of the Hubei Province for 2019 were provided by the National Bureau of Statistics of the People's Republic of China (www.stats.gov.cn). Domestic commuting routes data for the DRC were based on the available data provided by the World bank, the United Nations Joint Logistic Center and Economic Commission for Africa and the African Development Bank. Due to the lack of a population census in the DRC, the population was estimated at 54 million (2005) based on the number of registered voters in the 2005 election, assuming that all registered voters represent $33 \%$ of the total population in each province. All data are expressed as the mean \pm SEM. All data were analyzed on GraphPad Prism version 8.0.1 (GraphPad Software, Inc.). Population data are

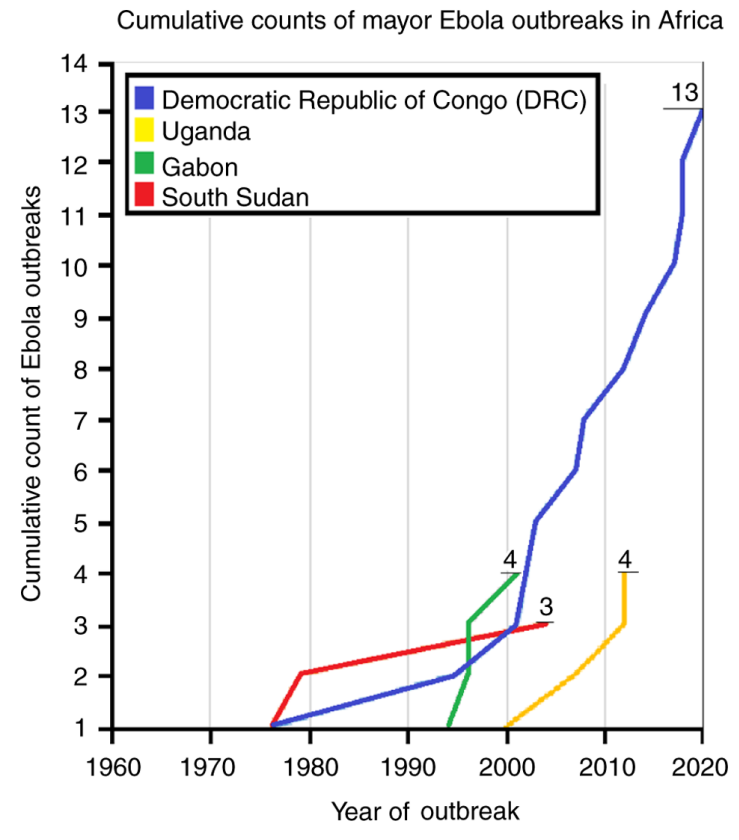

Figure 1. Cumulative count of Ebola outbreaks and recurrent cases within majorly affected countries. Data from 1960 to 2020 in The Democratic Republic of Congo, Uganda, Gabon and South Sudan are shown. Lines end at the year of the latest outbreak in the respective countries.

also presented in quartiles, including the minimum value, first quartile, median value, third quartile and the maximum value.

\section{Results}

Recurrent outbreaks. Although the largest Ebola outbreaks in 2014-2015 were reported in Liberia, Guinea and Sierra Leone, there were only four other countries with relevant $>2$ outbreaks in recorded history. These are Gabon, Uganda, South Sudan and the DRC (www.who.int). Among the 13 outbreaks that previously occurred, the DRC experienced the highest frequency of Ebola outbreaks among these countries (Fig. 1). Whilst the incidence of Ebola in Gabon, Uganda and South Sudan appears to have decreased since the initial reports, the opposite is true for DRC, with an increasing trend in Ebola outbreaks since 1976. This observation remains inexplicable at present.

Aviation network. The analysis of the international aviation network yielded notable similarities between Kinshasa, the capital city of the DRC and Wuhan, the capital of Hubei, China. Both are international flight destinations that are heavily frequented in their respective continents. Whilst $86 \%$ of the flights arriving and departing from Kinshasa are from the African continent, $79 \%$ of the flights to and from the Hubei province are from the Asian continent and Australia. Extracontinental destinations account for $<25 \%$ of the flights of both airports. The total number of international passengers per year is 489,652 for Kinshasa and 2,920,000 for Wuhan. However, the total passenger number for Wuhan is $>30$-fold higher ( 24 million) compared with the number for Kinshasa ( 773,338). To highlight the high volume of flights at Kinshasa airport compared with that in other African destinations, the cumulative numbers of the three international airports in the capital cities of Sierra Leone (Freetown, 227,649), Liberia 
A

Presentation of main international flight destination of Kinshasa and Wuhan International Airports
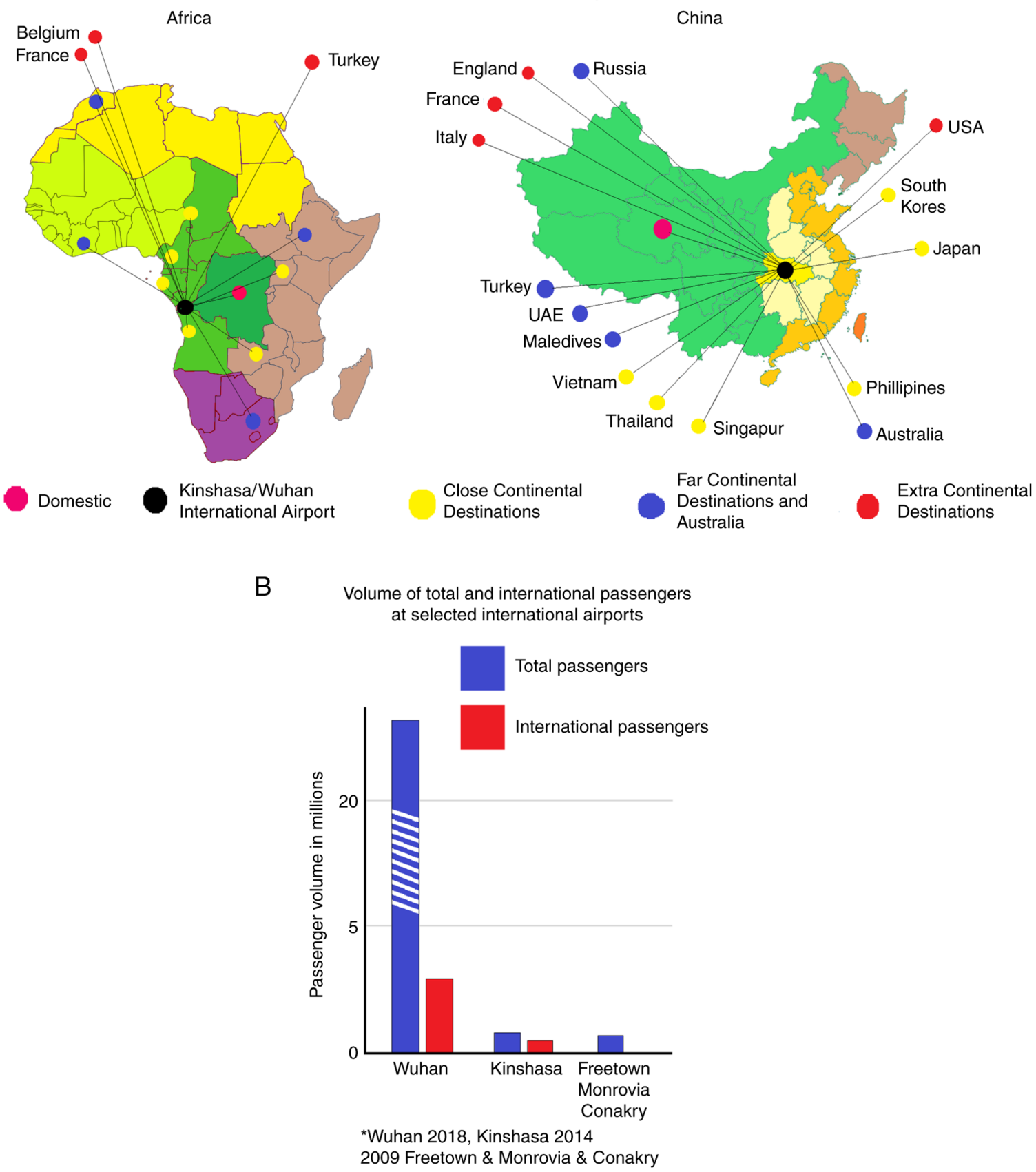

Figure 2. Air travel analysis. (A) Maps of Africa and China, where the main international flight destinations from Kinshasa and Wuhan International Airports are presented. Locations are grouped according to domestic (pink), close continental destinations (yellow), far continental destinations (blue) and extracontinental destinations (red). (B) Volume of both total and international passengers at selected international airports. Passenger volume is presented as millions per year. Passenger volumes at the International airports of Freetown (capital of Sierra Leone), Monrovia (capital of Liberia) and Conakry (capital of Guinea) were combined for comparison. These countries were selected as they were part of recent Ebola outbreaks. UAE, United Arab Emirates.

(Monrovia, 133,656) and Guinea (Conakry, 360,000) amounts to 660,000 passengers in total (Fig. 2).

Transportation network other than aviation and population density. The transportation networks leading out of the DRC and Hubei are similar. For both the city of Wuhan and the DRC, the main transportation network is based on roads and highways. However, roads clearly dominate the mode of travel between Hubei province and its surrounding provinces. For the DRC, traveling to neighboring countries is mostly achieved using water routes, which is the second most frequented mode of transport in the DRC. This is in contrast to Hubei, where the railway is the second most common mode of transport (Fig. 3B). Data on the total passenger volume of these different modes of transport for DRC and Hubei were not available and therefore could not be compared with data already presented for aviation passenger volume. Data on population density not only demonstrate that the density in the DRC is far lower compared with that in the Hubei province, but that the population in Hubei province is also more evenly distributed. By 

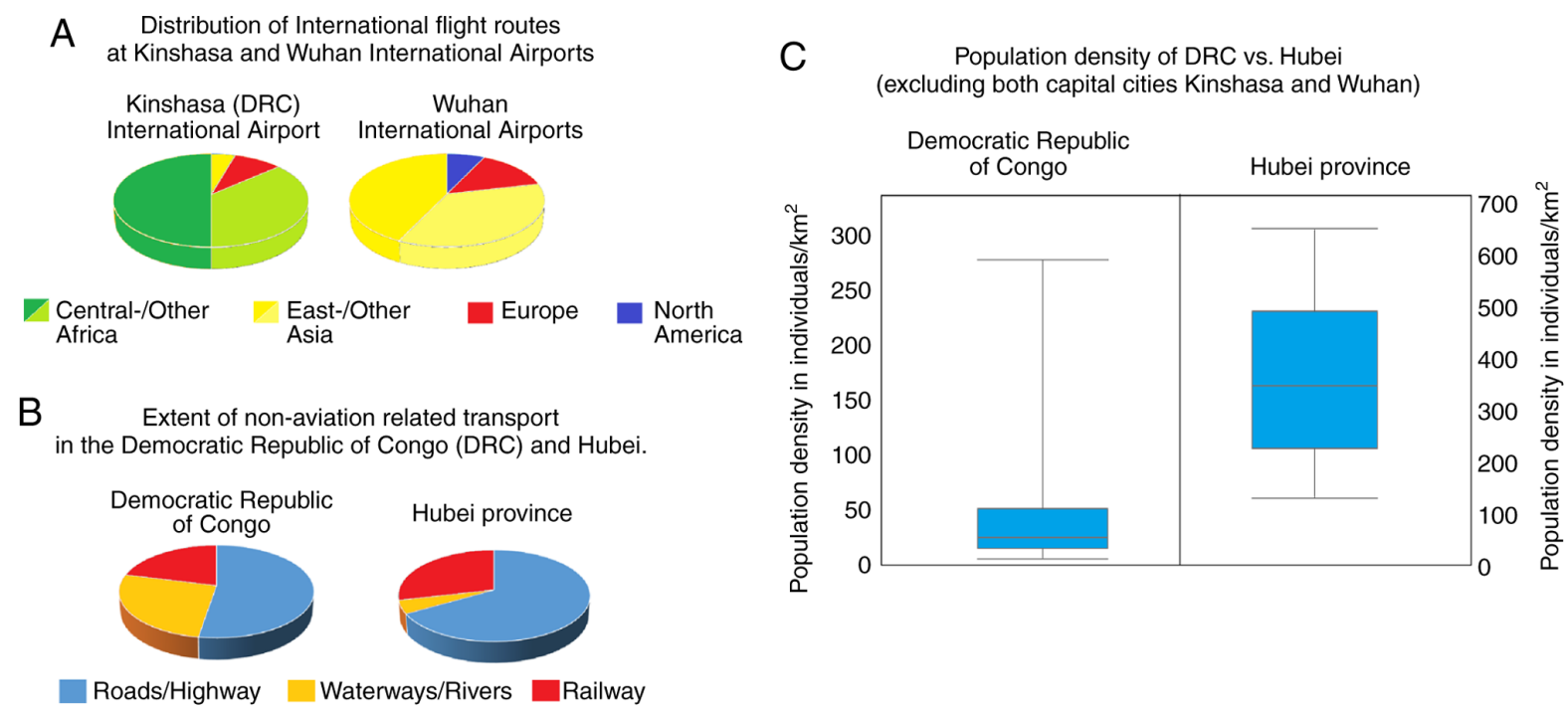

Figure 3. Flight destinations and domestic travel routes. (A) Distribution of international flight routes at Kinshasa and Wuhan International airports. Continents are marked in their respective colors: Africa (green), Asia (yellow), North America (blue) and Europe (red). (B) Proportion of non-aviation transport in the DRC and Hubei. The modes of non-aviation transport was divided further into the sectors 'roads and highways', 'waterways, rivers and canals' and 'railway'. (C) Comparison of population density and distribution in DRC and Hubei (excluding Kinshasa and Wuhan). DRC, Democratic Republic of Congo.

contrast, the DRC has some densely populated areas, but also numerous sparsely populated regions (Fig. 3C).

\section{Discussion}

Increasing human infringement into the African rainforest has long been suspected to potentially increase the risk of an Ebola outbreak $(10,11)$. To the best of our knowledge, the present study is the first to document the marked association of population density, air-traffic profiles and transportation. It was also the first study to compare these aspects between the DRC and the Hubei province, which was the center of the current COVID-19 pandemic.

Only limited data are available from the Congo, and at the moment, the regional Ebola spread remains limited to the DRC. However, considering the extensive data accessible for COVID-19, particularly as regards mutations and new strain developments, commuting remains the key factor in disease spread (9). The present study demonstrates the striking similarities between COVID and a potential Ebola pandemic, based on the knowledge gathered during the COVID-19 pandemic. Data from the present study suggest that there is a real threat of an international Ebola pandemic due to an uncontained local outbreak in Kinshasa.

Furthermore, a comparison of the epidemiological data from the present study with those from the COVID-19 pandemic is now possible, which serves as a valuable reference to facilitate the thorough understanding of how a pandemic can develop in the near future. The main differences found between the DRC and Hubei province in the present study are population density and the volume of domestic air travel within the country. The DRC is tied within the international aviation corridors in a manner that is comparable to Hubei. Although it was not possible to comprehensively quantify the extent of domestic commute via other modes of transport, it is safe to assume that passenger numbers are higher in Hubei compared with those in the DRC. However, it is worth remembering that in the case of COVID-19, multiple Chinese metropoles were affected. This may have further aggravated the international spread of COVID-19. If these other Chinese metropoles were excluded from the analysis and only Wuhan was focused upon as the epicenter of viral spread, an international air traffic profile that closely resembles the infrastructure present in the DRC may be found. Although the previous Ebola outbreak was relatively widespread with cases observed in countries including Liberia, Sierra Leone and Guinea, only a small number of international cases were found. In addition, the international airports of their respective capital cities only harbored small international passenger capacities with few foreign travelers in the affected areas.

Therefore, the present study supports the hypothesis that two different basic modes of viral spread must be distinguished in an outbreak scenario. The first mode includes disease spread along the physical borders of a country, which is supported by transportation by roads, water routes and railway. This spread pattern is mostly continuous, relatively slow and therefore has a measurable effect. The second mode presents disease spread fueled by international air travel, where unexpected cases can typically occur far outside the outbreak zone with a seemingly erratic distribution pattern. However, this spread pattern and its associated risks can be traced back to the specific flight destinations and total passenger volumes (9). Indeed, Ebola tends to have a different spread pattern, incubation time and risk profile compared with COVID-19. Airborne transmission is one of the key reasons underlying the ability of COVID-19 to spread rapidly and develop into a pandemic $(12,13)$. By contrast, Ebola, despite being more lethal, is mainly transmitted through blood and excreta (14). From a biological perspective, this mode of transmission would only result in limited transmission patterns, whilst the potential profile of global spread would be highly complex. Therefore, controlling the spread of Ebola is easier compared with COVID-19. 
Concerns for a potential Ebola epidemic have been previously discussed, particularly following larger outbreaks in West Africa between 2013 and 2016 (15,16), since then attention has been shifted towards investigating the molecular and evolutionary aspects of the Ebola virus $(2,17)$. In fact, recent data raise some concern with respect to the evolutionary changes in Ebola biology and the routes of transmission. Recent studies were able to demonstrate the pulmonary involvement of Ebola (18) and the ongoing adaptation of the virus to new species (19). Another new concerning development are reports of Ebola virus transmission by a selective group of individuals known as persistently infected survivors (20). Global health organizations and western countries should coordinate their efforts to increase Ebola awareness and establish additional watch centers in order to prevent the global disease spread, despite the increasing volume and ease of international travel to a wide range of travel destinations. However, the risk evaluation of the infrastructural aspects associated with disease outbreaks can yield similar profiles regardless of the type of virus that causes them. For COVID-19, the aforementioned biological factors may serve a significant role in the development of a pandemic in addition to the factors of domestic spread within the zone of outbreak. Despite recurrent Ebola outbreaks over the past decades, there has been a false narrative whereby Ebola is only restricted to a specific, remote region of the world where it is well-contained. However, this may change going forward, since previous reports indicate that a number of travelers from the DRC and Guinea have been placed under quarantine in the State of Washington (https://www.cdc.gov/quarantine/order-contact-information-ebola.html, https://www.cdc. gov/media/releases/2021/s0226-drc-ebola.html and https://www. doh.wa.gov/Newsroom/Articles/ID/2708/Public-health-officialsmonitor-low-risk-travelers-from-Ebola-affected-regions), USA, due to possible Ebola exposure. In fact, the state of Washington was also one of the first states in the USA where COVID-19 cases were identified, which rapidly developed into a major threat to the health of the entire country and even the continent (21). Unfortunately, it is still widely believed that the same strain of Ebola virus is combatted in every outbreak, which is not only incorrect, but also provides a false sense of security. In fact, over time, changes have been observed in the biological characteristics of the virus due to mutations. Should a more aggressive and stable variant of the Ebola virus that is more contagious appear, this could result in a global pandemic and would take the international community by surprise. A comparison of risk factors between the current COVID-19 pandemic and a possible Ebola outbreak revealed striking similarities, such as considerable respective morbidity and mortality rates which undermine social and economic activities, similar incubation times and initial unspecific symptoms which can be misinterpreted, as well as rapid transmission which can occur during a brief contact, due to exposure to a critical amount of viral load $(2,22)$. In fact, if the biological aspects and particular differences in transmission are not considered, there are only a small number of differences in the risk profiles of the COVID-19 pandemic and those of a possible Ebola pandemic.

The observed differences in the present study are restricted to higher volumes of domestic commute within China, as well as a higher population density. The notion that Ebola is a disease limited to a remote area of the globe is becoming obsolete, considering that it has previously already reached
Kinshasa, the capital city of the DRC and a major African metropolitan city. To prevent a global pandemic, increased awareness must be achieved on this issue, such that resources are shifted towards creating centers that can observe, monitor and control local outbreaks.

\section{Acknowledgements}

Not applicable.

\section{Funding}

No funding was received.

\section{Availability of data and materials}

The datasets used and/or analyzed during the current study are available from the corresponding author on reasonable request.

\section{Authors' contributions}

MA was involved in data interpretation, conception and design of the study and in the critical revision of the manuscript for important intellectual content. IAO, JS, JK and MKL were involved in data interpretation and in the drafting of the manuscript. JB and PF were involved in data analysis and interpretation and in the drafting of the manuscript. VK was involved in data interpretation and in the critical revision of the manuscript for important intellectual content. PF was involved in data acquisition and in the drafting of the manuscript. TK was involved in the conception and design of the study, in analysis and interpretation, and in the critical revision of the manuscript for important intellectual content. MA, IAO, MKL and VK confirm the authenticity of the raw data. All authors have read and approved the submitted and final manuscript.

\section{Ethics approval and consent to participate}

Not applicable.

\section{Patient consent for publication}

Not applicable.

\section{Competing interests}

The authors declare that they have no competing interests.

\section{References}

1. Lau H, Khosrawipour V, Kocbach P, Mikolajczyk A, Ichii H, Zacharski M, Bania J and Khosrawipour T: The association between international and domestic air traffic and the coronavirus (COVID-19) outbreak. J Microbiol Immunol Infect 53: 467-472, 2020.

2. Malvy D, McElroy AK, de Clerck H, Günther S and van Griensven J: Ebola virus disease. Lancet 393: 936-948, 2019.

3. Nanclares C, Kapetshi J, Lionetto F, de la Rosa O, Tamfun JJ, Alia M, Kobinger G and Bernasconi A: Ebola virus disease, democratic Republic of the Congo, 2014. Emerg Infect Dis 22: 1579-1586, 2016 
4. Park DJ, Dudas G, Wohl S, Goba A, Whitmer SL, Andersen KG, Sealfon RS, Ladner JT, Kugelman JR, Matranga CB, et al: Ebola virus epidemiology, transmission, and evolution during seven months in sierra leone. Cell 161: 1516-1526, 2015.

5. LaBrunda $M$ and Amin N: The emerging threat of ebola. In: Global Health Security. Advanced Sciences and Technologies for Security Applications. Masys A, Izurieta R and Reina Ortiz M (eds). Springer, Cham, pp103-139, 2020.

6. Lau H, Khosrawipour V, Kocbach P, Mikolajczyk A, Schubert J, Bania J and Khosrawipour T: The positive impact of lockdown in Wuhan on containing the COVID-19 outbreak in China. J Travel Med 27: taaa037, 2020.

7. Khosrawipour V, Lau H, Khosrawipour T, Kocbach P, Ichii H, Bania J and Mikolajczyk A: Failure in initial stage containment of global COVID-19 epicenters. J Med Virol 92: 863-867, 2020.

8. Lau H, Khosrawipour T, Kocbach P, Ichii H, Bania J and Khosrawipour V: Evaluating the massive underreporting and undertesting of COVID-19 cases in multiple global epicenters. Pulmonology 27: 110-115, 2021.

9. Lau H, Khosrawipour V, Kocbach P, Mikolajczyk A, Ichii H, Schubert J, Bania J and Khosrawipour T: Internationally lost COVID-19 cases. J Microbiol Immunol Infect 53: 454-458, 2020.

10. Rulli MC, Santini M, Hayman DT and D'Odorico P: The nexus between forest fragmentation in Africa and ebola virus disease outbreaks. Sci Rep 7: 41613, 2017.

11. Alirol E, Getazv L, Stoll B, Chappuis F and Loutan L: Urbanisation and infectious diseases in a globalised world. Lancet Infect Dis 11: 131-141, 2011.

12. Setti L, Passarini F, De Gennaro G, Barbieri P, Perrone MG, Borelli M, Palmisani J, Di Gilio A, Piscitelli P and Miani A: Airborne transmission route of COVID-19: Why 2 meters/ 6 feet of inter-personal distance could not be enough. Int J Environ Res Public Health 17: 2932, 2020.

13. Arafkas M, Khosrawipour T, Kocbach P, Zielinski K, Schubert J, Mikolajczyk A, Celinska M and Khosrawipour V: Current meta-analysis does not support the possibility of COVID-19 reinfections. J Med Virol 93: 1599-1604, 2021.
14. Judson S, Prescott J and Munster V: Understanding ebola virus transmission. Viruses 7: 511-521, 2015.

15. Burd EM: Ebola virus: A clear and present danger. J Clin Microbiol 53: 4-8, 2015

16. Kekulé AS: Learning from ebola virus: How to prevent future epidemics. Viruses 7: 3789-3797, 2015.

17. Holmes EC, Dudas G, Rambaut A and Andersen KG: The evolution of ebola virus: Insights from the 2013-2016 epidemic. Nature 538: 193-200, 2016.

18. Lalle E, Biava M, Nicastri E, Colavita F, Di Caro A, Vairo F, Lanini S, Castilletti C, Langer M, Zumla A, et al: Pulmonary involvement during the ebola virus disease. Viruses 11: 780, 2019.

19. Pappalardo M, Reddin IG, Cantoni D, Rossman JS, Michaelis M and Wass MN: Changes associated with ebola virus adaptation to novel species. Bioinformatics 33: 1911-1915, 2017.

20. Subissi L, Keita M, Mesfin S, Rezza G, Diallo B, Van Gucht S, Musa EO, Yoti Z, Keita S, Djingarey MH, et al: Ebola virus transmission caused by persistently infected survivors of the 2014-2016 outbreak in West Africa. J Infect Dis 218 (Suppl 5): S287-S291, 2018.

21. Bhatraju PK, Ghassemieh BJ, Nichols M, Kim R, Jerome KR, Nalla AK, Greninger AL, Pipavath S, Wurfel MM, Evans L, et al: Covid-19 in critically Ill patients in the seattle region-case series. N Engl J Med 382: 2012-2022, 2020.

22. Wiersinga WJ, Rhodes A, Cheng AC, Peacock SJ and Prescott HC: Pathophysiology, transmission, diagnosis, and treatment of coronavirus disease 2019 (COVID-19): A review. JAMA 324: 782-793, 2020

This work is licensed under a Creative Commons Attribution-NonCommercial-NoDerivatives 4.0 International (CC BY-NC-ND 4.0) License. 